\title{
Environmental radionuclide concentrations below which non-human biota experience no effects
}

\author{
S.L. Chouhan, T.L. Yankovich and P.A. Davis \\ AECL, Chalk River, KOJ 1J0 Ontario, Canada \\ e-mail: chouhans@aecl.ca
}

\begin{abstract}
Conservative no-effect concentrations were derived for nine radionuclides, four generic organisms (terrestrial plant and animal and aquatic plant and animal) and six environmental compartments (air, soil, fresh water, marine water, freshwater sediments and marine sediments). The concentrations were calculated using the concentration ratio (CR) approach that is used in both FASSET and RESRAD-BIOTA. In the CR approach, a single transfer factor is used to predict concentrations in plants or animals from concentrations in soil or water. Most of the CR values required for the calculations were taken from FASSET documentation. Because of the importance of tritium and C-14 in the context of CANDU reactors, $\mathrm{CR}$ values for these radionuclides were derived from specific activity (SA) concepts. Sediment partition coefficient $\left(\mathrm{K}_{\mathrm{d}}\right)$ values, which were used to derive no-effect levels for sediments from the levels for water, were chosen to be the best-estimate values from the IMPACT database. Dose conversion coefficients (DCCs) were taken from FASSET and the dose rate benchmarks used were those recommended by UNSCEAR. The results provide environmental concentrations below which no detrimental effects are expected on non-human biota at CANDU sites in Canada.
\end{abstract}

\section{INTRODUCTION}

Canadian nuclear facility owners must demonstrate that non-human biota are protected from the effects of radionuclide releases during the normal operation of their sites. To help meet this requirement, a summary table was developed listing generic, conservative environmental concentrations of relevant CANDU radionuclides below which no effects are expected on non-human biota [1].

\section{MODEL DESCRIPTION}

\subsection{General approach}

We reviewed three available approaches [2-4] for estimating doses to non-human biota, and adopted the concentration ratio (CR) approach used in FASSET [2] and RESRAD-BIOTA [3]. The CR approach uses a single transfer factor to predict concentrations in plants or animals from concentrations measured in air, soil, water or sediments. Internal doses to the biota were calculated by multiplying the plant or animal concentrations by an internal dose conversion coefficient (DCC). External doses were found by multiplying the environmental concentration by an external DCC. The no-effect concentrations were then calculated by dividing the dose into the dose rate benchmark, the dose rate to which organisms can be exposed without detriment. Sediment partition coefficient $\left(\mathrm{K}_{\mathrm{d}}\right)$ values were used as effective CRs to derive no-effect levels for sediments from the levels for water. Figures 1 and 2 provide a schematic representation of this general approach for terrestrial and aquatic systems respectively.

We calculated no-effect concentrations for nine radionuclides commonly found in the effluent of CANDU reactors: tritium, C-14, Co-60, Sr-90, Zr-95, Nb-95, I-131, Cs-134 and Cs-137. In each case, we considered four generic organisms: a terrestrial plant, a terrestrial animal, an aquatic plant and an aquatic animal, each of which was treated conservatively. For a given radionuclide and pathway, the CR for each generic organism was chosen to be the largest among all the reported FASSET CRs for all 


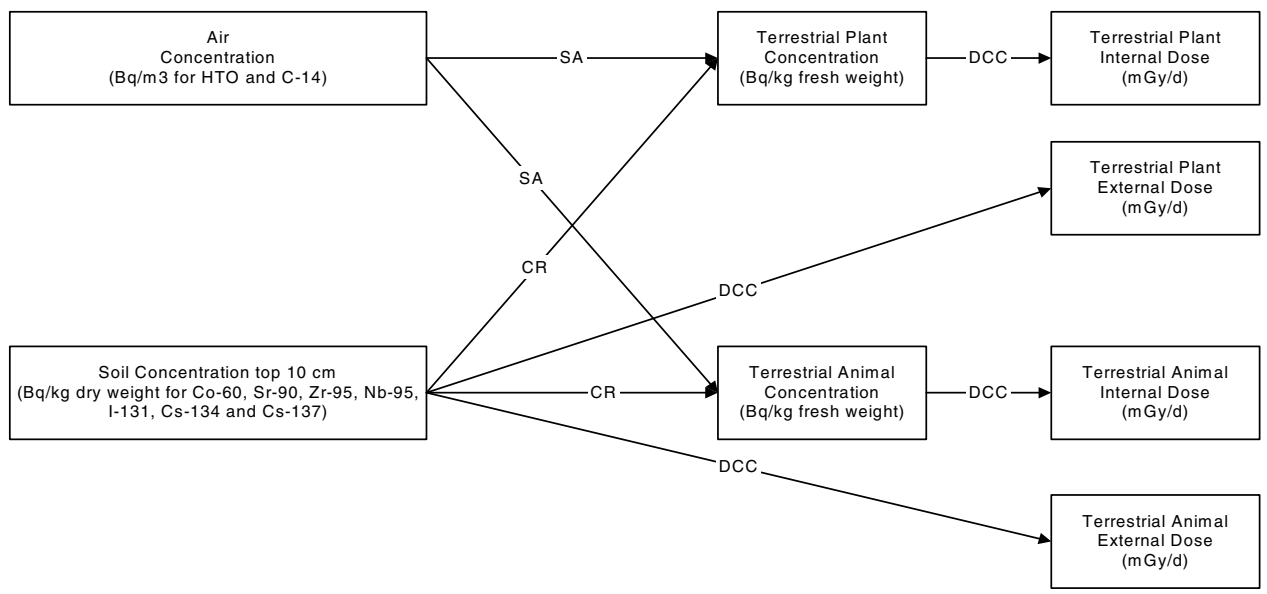

Figure 1. Schematic representation of the calculation of no-effect concentrations for terrestrial pathways. The notation "SA" means that the CRs for HTO and C-14 were determined from specific activity considerations.

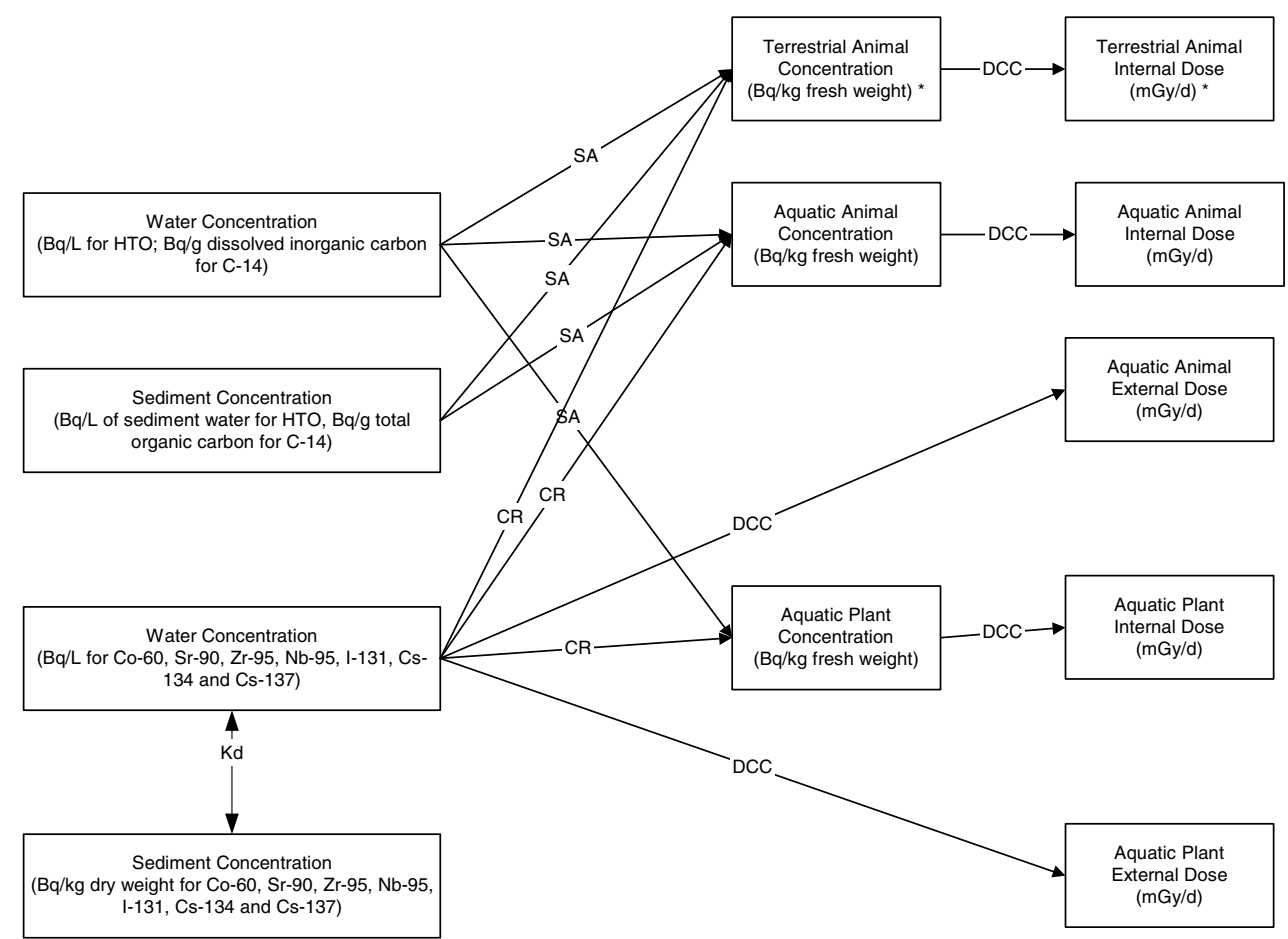

Figure 2. Schematic representation of the calculation of no-effect concentrations for aquatic pathways. All pathways and compartments apply to the freshwater system, and all compartments except the two terrestrial animal compartments (marked by *) apply to the marine system. The notation "SA" means that the CRs for HTO and C-14 were determined from specific activity considerations.

organisms in that category. We compared the aquatic CRs further with the values given in IMPACT [4] and used whichever was higher. Similarly, the DCCs were chosen to be the largest among all the reported FASSET DCCs. In this way, our generic organisms are conservative with respect to both environmental 
transfer and dose, and our calculated no-effect concentrations will protect all organisms in each generic category.

The dose rate benchmarks were selected as $1 \mathrm{mGy} / \mathrm{d}$ for terrestrial animals, and $10 \mathrm{mGy} / \mathrm{d}$ for terrestrial plants, aquatic animals and aquatic plants [5]. The aquatic benchmarks apply to the maximum exposed individual, for which large sample sizes are available, but the remaining benchmarks are for average members of a population because sample sizes are not usually large enough to treat individuals.

\subsection{Calculation of no-effect concentrations}

The calculations started with a unit concentration $\left(\mathrm{C}_{\mathrm{e}}\right)$ in a given environmental compartment. The concentration in the reference organism of interest $\left(\mathrm{C}_{\mathrm{o}}\right)$ was then calculated from

$$
\mathrm{C}_{\mathrm{o}}=\mathrm{CRC}_{\mathrm{e}}
$$

where $\mathrm{CR}$ is the concentration ratio for the given radionuclide, organism and pathway. The external dose to the organism $\left(D_{\mathrm{e}}\right)$ was given by

$$
\mathrm{D}_{\mathrm{e}}=\mathrm{DCC}_{\mathrm{e}} \mathrm{C}_{\mathrm{e}}
$$

where $\mathrm{DCC}_{\mathrm{e}}$ is the external dose conversion coefficient. The internal dose to the organism $\left(\mathrm{D}_{\mathrm{i}}\right)$ was calculated from

$$
\mathrm{D}_{\mathrm{i}}=\mathrm{DCC}_{\mathrm{i}} \mathrm{C}_{\mathrm{o}}
$$

where $\mathrm{DCC}_{\mathrm{i}}$ is the internal dose conversion coefficient. The total dose to the organism (D) from a unit concentration in the respective environmental compartment was given by

$$
\mathrm{D}=\mathrm{D}_{\mathrm{e}}+\mathrm{D}_{\mathrm{i}}
$$

The no-effect concentration $\left(\mathrm{C}_{\mathrm{nel}}\right)$ was then calculated from

$$
\mathrm{C}_{\mathrm{nel}}=\mathrm{DRB} / \mathrm{D}
$$

where DRB is the dose rate benchmark. The generic no-effect concentration for a given radionuclide in a given compartment was then found as the minimum no-effect value among the concentrations for total doses to plants and animals. The no-effect concentrations for sediments were found by multiplying the no-effect level concentration for water by the appropriate $\mathrm{K}_{\mathrm{d}}$ value.

\section{PARAMETER VALUES}

\subsection{Concentration ratios}

\subsubsection{Tritium}

The CR values for tritium were derived from specific activity (SA) concepts, assuming that the tritium concentration (in $\mathrm{Bq} / \mathrm{L}$ ) was the same in all aqueous parts of the environment, including the combustion water of dry matter, which accounts for organically bound tritium (OBT). However, the dose coefficients for non-human biota are expressed in terms of $\mathrm{Bq} / \mathrm{kg}$ fresh weight (fw) rather than $\mathrm{Bq} / \mathrm{L}$. In our calculations, the required concentrations in $\mathrm{Bq} / \mathrm{kg}$ fw were assumed to equal the calculated concentrations in $\mathrm{Bq} / \mathrm{L}$. This yielded slightly conservative results and meant that water contents and water equivalents did not have to be determined for the specific organisms considered. Moreover, it was not necessary to apply separate dose coefficients for tritiated water (HTO) and OBT because retention time is not an issue under full equilibrium conditions. 
3.1.1.1 Terrestrial pathways. No-effect concentrations were calculated for air only, since air concentrations are most easily measured and provide a good estimate of long-term average conditions. The concentrations in all terrestrial organisms (in $\mathrm{Bq} / \mathrm{kg}$ fw) were set equal to the concentration in air moisture (in $\mathrm{Bq} / \mathrm{L}$ ):

$$
\mathrm{C}_{\mathrm{o}}=\mathrm{C}_{\mathrm{a}} / \mathrm{H}_{\mathrm{a}}
$$

where $\mathrm{C}_{\mathrm{a}}$ the concentration in air $\left(\mathrm{Bq} / \mathrm{m}^{3}\right)$ and $\mathrm{H}_{\mathrm{a}}$ is the absolute humidity $\left(\mathrm{kg} / \mathrm{m}^{3}\right)$. The $\mathrm{CR}$ for the transfer of HTO from air to terrestrial organisms is therefore equal to $1 / \mathrm{H}_{\mathrm{a}}$. Since low values of $\mathrm{H}_{\mathrm{a}}$ are conservative, we used the annual average in our calculations, since this is smaller than the average over any other relevant interval. The annual average for eastern Canada is $0.007 \mathrm{~L} / \mathrm{m}^{3}$, implying that the CR for the transfer of HTO from air to terrestrial organisms is 143 .

3.1.1.2 Aquatic pathways. No-effect concentrations were calculated for fresh water, marine water, freshwater sediments and marine sediments. Following the assumptions in section 3.1.1, the concentrations in all aquatic organisms (in $\mathrm{Bq} / \mathrm{kg}$ fw) were set equal to the concentration in water (in $\mathrm{Bq} / \mathrm{L}$ ). Thus, the CR for the transfer of HTO from water to aquatic organisms is simply 1 . The CR for the transfer of HTO from water (or sediment) to terrestrial animals due to drinking was also conservatively assumed to be 1 . This is a reasonable assumption since most animals derive the greater part of their water from drinking.

\subsubsection{Carbon-14}

The C-14 model was also based on the assumption of full specific activity equilibrium in all environmental compartments. This is a good approximation for atmospheric releases, where $\mathrm{C}-14$ is emitted almost entirely as ${ }^{14} \mathrm{CO}_{2}$, the form in which it is taken up by plants. Moreover, animals take up carbon almost entirely through ingestion. The situation is more complicated for aquatic releases, since there are several carbon pools in aquatic systems. With a few exceptions, the calculations for the aquatic compartments were based on dissolved inorganic carbon (DIC), the form of carbon taken up by aquatic plants and used in photosynthesis. The exceptions were sediments, benthic fish and filter feeders, for which the no-effect levels were based on total organic carbon (TOC), since C-14 concentrations in these organisms near CANDU power stations are similar to those in TOC [6].

The specific activity model for $\mathrm{C}-14$ was formulated in terms of the activity per g stable carbon. It was necessary to convert to concentrations expressed in $\mathrm{Bq} / \mathrm{kg}$ fw to accommodate the dose coefficients, which implies that the stable carbon concentration had to be known for each organism.

3.1.2.1 Terrestrial pathways. As with tritium, no-effect levels were calculated for air only. The concentrations in all terrestrial organisms (in $\mathrm{Bq} / \mathrm{g} \mathrm{C}$ ) were set equal to the concentration in air (in $\mathrm{Bq} / \mathrm{g} \mathrm{C}$ ). The relationship between the concentration in the organism in $\mathrm{Bq} / \mathrm{kg}$ fw and the concentration in air in $\mathrm{Bq} / \mathrm{m}^{3}$ was thus given by:

$$
\mathrm{C}_{\mathrm{o}}=\mathrm{M}_{\mathrm{o}} \mathrm{C}_{\mathrm{a}} / \mathrm{M}_{\mathrm{a}}
$$

where $\mathrm{M}_{\mathrm{o}}(\mathrm{g} / \mathrm{kg} \mathrm{fw})$ and $\mathrm{M}_{\mathrm{a}}\left(=0.18 \mathrm{~g} / \mathrm{m}^{3}\right)$ are the masses of stable carbon in the organism and in air, respectively. CR for the transfer of C-14 from air to terrestrial organisms is therefore equal to $M_{o} / M_{a}$.

3.1.2.2 Aquatic pathways. No-effect concentrations were calculated for fresh water, marine water, freshwater sediments and marine sediments. The concentrations in all aquatic plants and pelagic fish (in $\mathrm{Bq} / \mathrm{gC}$ ) were set equal to the DIC concentration in water $\left(\mathrm{C}_{\mathrm{DIC}}, \mathrm{Bq} / \mathrm{gC}\right)$. The relationship between the concentration in these organisms in $\mathrm{Bq} / \mathrm{kg}$ fw and $\mathrm{C}_{\mathrm{DIC}}$ is therefore given by:

$$
\mathrm{C}_{\mathrm{o}}=\mathrm{M}_{\mathrm{o}} \mathrm{C}_{\mathrm{DIC}}
$$


where $\mathrm{M}_{\mathrm{o}}(\mathrm{g} / \mathrm{kg} \mathrm{fw})$ is the mass of stable carbon in the organism. CR for the transfer of C-14 from water to aquatic organisms is therefore equal to $\mathrm{M}_{\mathrm{o}}$. Equation (8) also describes the transfer of C-14 from water to terrestrial animals, so that the $C R$ for this pathway is also equal to $\mathrm{M}_{\mathrm{o}}$, on the assumption that the primary source of $\mathrm{C}-14$ in the drinking water is DIC.

Concentrations in benthic fish and filter feeders (in $\mathrm{Bq} / \mathrm{gC}$ ) are equal to the concentration of TOC in sediments $\left(\mathrm{C}_{\mathrm{TOC}}, \mathrm{Bq} / \mathrm{gC}\right)$. The relationship between the concentration in these organisms in $\mathrm{Bq} / \mathrm{kg} \mathrm{fw}$ and $\mathrm{C}_{\mathrm{TOC}}$ is therefore given by

$$
\mathrm{C}_{\mathrm{o}}=\mathrm{M}_{\mathrm{o}} \mathrm{C}_{\mathrm{TOC}}
$$

CR values for the transfer of C-14 from water to aquatic organisms is therefore also equal to $\mathrm{M}_{\mathrm{o}}$.

CR values for C-14 were calculated using Equations (6) to (9) for a number of different terrestrial and aquatic plants and animals. The highest CR for each category (table 1) was used to calculate the no-effect concentrations for a generic organism in that category.

Table 1. Generic organisms with the highest stable carbon concentrations and the highest C-14 CRs.

\begin{tabular}{|l|c|c|}
\hline \multicolumn{1}{|c|}{ Generic organism } & $\begin{array}{c}\text { Stable carbon } \\
\text { concentration * } \\
\text { (gC/kg fw) }\end{array}$ & CR \\
\hline Terrestrial plant (conservative value estimated using data from few plants) & 275 & 1530 \\
\hline Terrestrial animal (reptile) & 170 & 944 \\
\hline Aquatic plant (conservative value estimated using data from few plants) & 144 & 144 \\
\hline Aquatic animal (reptile) & 170 & 170 \\
\hline
\end{tabular}

* These assume a carbon concentration of $500 \mathrm{gC} / \mathrm{kg}$ dry weight ( $\mathrm{dw}$ ) for all species, a slightly conservative estimate, and generic values for the dry matter fraction $(\mathrm{kg} \mathrm{dw} / \mathrm{kg} \mathrm{fw})$ for each species.

\subsubsection{Other radionuclides}

Most of the CR values for radionuclides other than tritium and C-14 came from FASSET documentation, although some were taken from RESRAD-BIOTA and IMPACT. All of the values used in the calculation of no-effect levels are listed in table 2 and 3.

\subsection{Sediment partition coefficients and dose conversion coefficients}

The $\mathrm{K}_{\mathrm{d}}$ values were chosen to be the best-estimate values from the IMPACT database. Dose conversion coefficients (DCCs) were taken from FASSET (table 3).

\section{RESULTS AND CONCLUSIONS}

Generic no-effect concentrations for the 9 radionuclides and six environmental compartments considered in this study are shown in table 4 . These results are the environmental radionuclide concentrations below which no detrimental radiological effects are expected to non-human biota at Canadian CANDU sites. A comparison of the calculated no-effects levels with present and past measurements of environmental radionuclide concentrations indicates that the measured concentrations are orders of magnitude below the generic no-effect levels. Therefore, non-human biota are well protected from the effects of ionizing radiation under past and current operations at Canadian CANDU sites. 


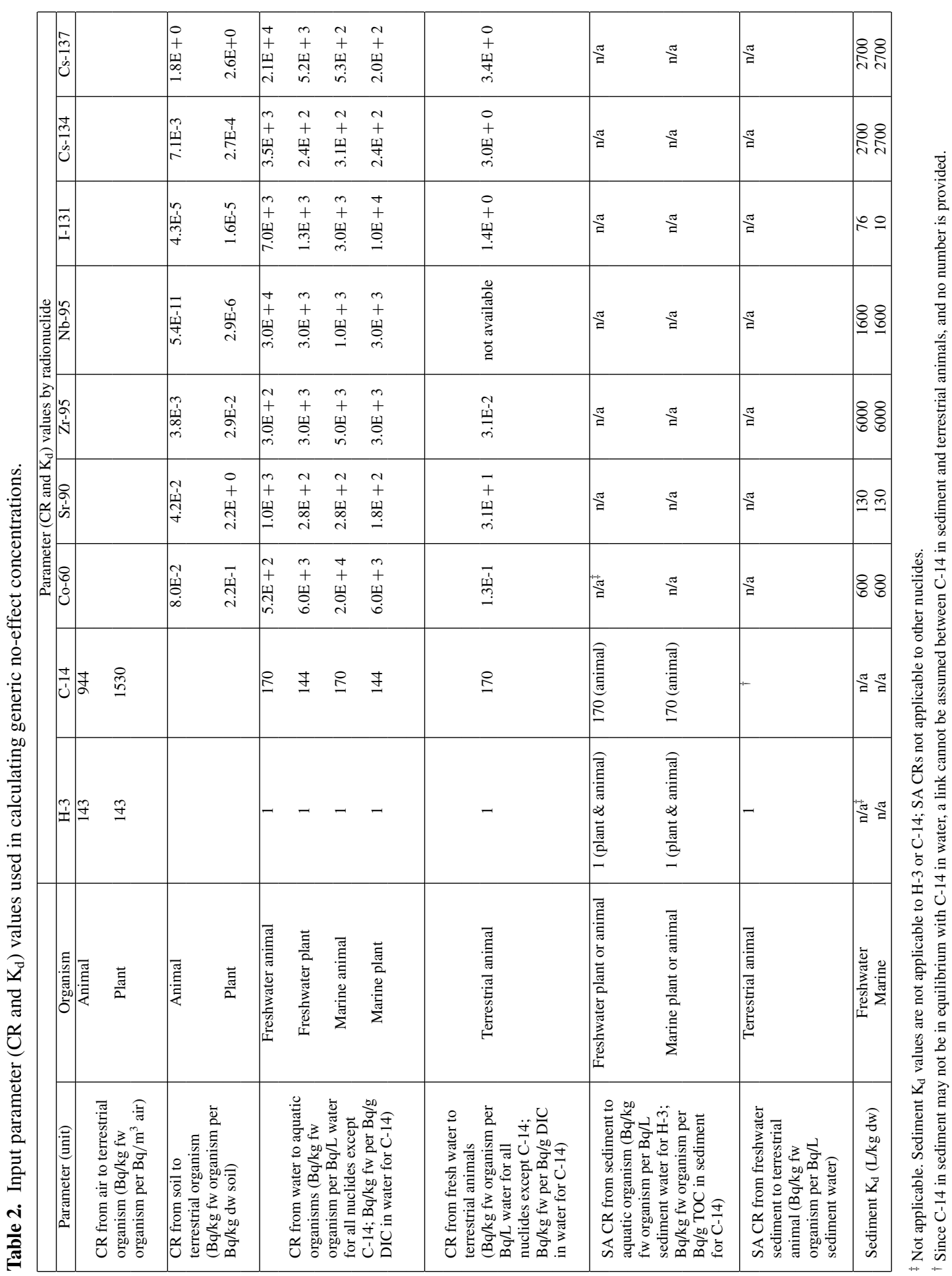


Table 3. Input parameter (DCCs) values used in calculating generic no-effect concentrations.

\begin{tabular}{|c|c|c|c|c|c|c|c|c|c|c|}
\hline \multirow{3}{*}{ Parameter (unit) } & & \multicolumn{9}{|c|}{ Parameter values (DCCs) by radionuclide } \\
\hline & Organism & $\mathrm{H}-3$ & $\mathrm{C}-14$ & Co-60 & Sr-90 & Zr-95 & $\mathrm{Nb}-95$ & $\mathrm{I}-131$ & Cs-134 & Cs-137 \\
\hline & Marine & $\mathrm{n} / \mathrm{a}$ & $\mathrm{n} / \mathrm{a}$ & 600 & 130 & 6000 & 1600 & 10 & 2700 & 2700 \\
\hline $\begin{array}{l}\text { External DCC for } \\
\text { terrestrial organisms }\end{array}$ & Animal & 0 & 0 & $3.6 \mathrm{E}-5$ & $2.6 \mathrm{E}-12$ & $2.3 \mathrm{E}-5$ & $3.9 \mathrm{E}-6$ & $1.9 \mathrm{E}-6$ & $7.7 \mathrm{E}-6$ & $2.9 \mathrm{E}-6$ \\
\hline $\begin{array}{l}\text { (mGy/d per Bq/kg dw } \\
\text { soil) }\end{array}$ & Plant & 0 & 0 & $3.6 \mathrm{E}-5$ & 2.6E-12 & $2.3 \mathrm{E}-5$ & $3.9 \mathrm{E}-6$ & $1.8 \mathrm{E}-6$ & $7.4 \mathrm{E}-6$ & $2.6 \mathrm{E}-6$ \\
\hline $\begin{array}{l}\text { External DCC for } \\
\text { freshwater organisms }\end{array}$ & Animal & 0 & 0 & $3.6 \mathrm{E}-5$ & $1.6 \mathrm{E}-5$ & $1.2 \mathrm{E}-5$ & $1.1 \mathrm{E}-5$ & $7.9 \mathrm{E}-6$ & $2.4 \mathrm{E}-5$ & $1.1 \mathrm{E}-5$ \\
\hline (mGy/d per Bq/L water) & Plant & 0 & 0 & $3.6 \mathrm{E}-5$ & $1.6 \mathrm{E}-5$ & $1.2 \mathrm{E}-5$ & $1.1 \mathrm{E}-5$ & 7.9E-6 & $2.4 \mathrm{E}-5$ & $1.1 \mathrm{E}-5$ \\
\hline $\begin{array}{l}\text { External DCC for marine } \\
\text { organisms }\end{array}$ & Animal & 0 & 0 & $3.6 \mathrm{E}-5$ & $1.6 \mathrm{E}-5$ & $1.2 \mathrm{E}-5$ & $1.1 \mathrm{E}-5$ & $7.9 \mathrm{E}-6$ & $2.4 \mathrm{E}-5$ & $1.1 \mathrm{E}-5$ \\
\hline (mGy/d per Bq/L water) & Plant & 0 & 0 & $3.6 \mathrm{E}-5$ & $1.6 \mathrm{E}-5$ & $1.2 \mathrm{E}-5$ & $1.1 \mathrm{E}-5$ & $7.9 \mathrm{E}-6$ & $2.4 \mathrm{E}-5$ & $1.1 \mathrm{E}-5$ \\
\hline $\begin{array}{l}\text { Internal DCC for } \\
\text { terrestrial organisms }\end{array}$ & Animal & $7.9 \mathrm{E}-8$ & $7.0 \mathrm{E}-7$ & $1.7 \mathrm{E}-5$ & $1.6 \mathrm{E}-5$ & $6.7 \mathrm{E}-6$ & $5.8 \mathrm{E}-6$ & $6.2 \mathrm{E}-6$ & $1.6 \mathrm{E}-5$ & $8.6 \mathrm{E}-6$ \\
\hline $\begin{array}{l}\text { (mGy/d per Bq/kg fw } \\
\text { organism) }\end{array}$ & Plant & $7.9 \mathrm{E}-8$ & $7.0 \mathrm{E}-7$ & $3.8 \mathrm{E}-6$ & $1.5 \mathrm{E}-5$ & $2.4 \mathrm{E}-6$ & $1.4 \mathrm{E}-6$ & $3.1 \mathrm{E}-6$ & $3.8 \mathrm{E}-6$ & $4.1 \mathrm{E}-6$ \\
\hline $\begin{array}{l}\text { Internal DCC for } \\
\text { freshwater organisms }\end{array}$ & Animal & $7.9 \mathrm{E}-8$ & $7.0 \mathrm{E}-7$ & $8.6 \mathrm{E}-6$ & $1.5 \mathrm{E}-5$ & $4.1 \mathrm{E}-6$ & $3.1 \mathrm{E}-6$ & $4.1 \mathrm{E}-6$ & $7.4 \mathrm{E}-6$ & $5.3 \mathrm{E}-6$ \\
\hline $\begin{array}{l}\text { (mGy/d per Bq/kg fw } \\
\text { organism) }\end{array}$ & Plant & $7.9 \mathrm{E}-8$ & $5.8 \mathrm{E}-7$ & 8.6E-7 & $1.5 \mathrm{E}-6$ & $9.1 \mathrm{E}-7$ & $5.3 \mathrm{E}-7$ & $1.0 \mathrm{E}-6$ & 7.9E-7 & $1.0 \mathrm{E}-6$ \\
\hline $\begin{array}{l}\text { Internal DCC for marine } \\
\text { organisms }\end{array}$ & Animal & $7.9 \mathrm{E}-8$ & $7.0 \mathrm{E}-7$ & $1.7 \mathrm{E}-5$ & $1.6 \mathrm{E}-5$ & $6.7 \mathrm{E}-6$ & $5.8 \mathrm{E}-6$ & $5.5 \mathrm{E}-6$ & $1.3 \mathrm{E}-5$ & $7.4 \mathrm{E}-6$ \\
\hline $\begin{array}{l}\text { (mGy/d per } \mathrm{Bq} / \mathrm{kg} \mathrm{fw} \\
\text { organism) }\end{array}$ & Plant & $7.9 \mathrm{E}-8$ & $7.0 \mathrm{E}-7$ & $3.8 \mathrm{E}-6$ & $1.5 \mathrm{E}-5$ & $2.4 \mathrm{E}-6$ & $1.4 \mathrm{E}-6$ & $3.1 \mathrm{E}-6$ & $3.8 \mathrm{E}-6$ & $4.1 \mathrm{E}-6$ \\
\hline
\end{tabular}

Table 4. Generic radionuclide concentrations below which no radiological effects are expected on non-human biota at Canadian CANDU sites.

\begin{tabular}{|l|c|c|c|c|c|c|}
\hline Nuclide & $\begin{array}{c}\text { Air concentration } \\
\text { soil })\end{array}$ & $\begin{array}{c}\text { Soil concentration } \\
(\mathrm{Bq} / \mathrm{L} \text { water }) \ddagger \\
\left(\mathrm{Bq} / \mathrm{m}^{3}\right)\end{array}$ & $\begin{array}{c}\text { Fresh water } \\
\text { concentration } \\
(\mathrm{Bq} / \mathrm{kg} \text { dry weight } \\
\text { soil })\end{array}$ & $\begin{array}{c}\text { Marine water } \\
\text { concentration } \\
(\mathrm{Bq} / \mathrm{L} \text { dry weight }) \ddagger\end{array}$ & $\begin{array}{c}\text { Freshwater sediment } \\
\text { concentration } \\
\mathrm{Bq} / \mathrm{L} \text { dry weight }) \ddagger \\
\text { sediment }\end{array}$ & $\begin{array}{c}\text { Marine sediment } \\
\text { concentration } \\
\text { Bq/L dry weight }) \ddagger \\
\text { sediment }\end{array}$ \\
\hline $\mathrm{H}-3$ & $8.84 \mathrm{E}+04$ & $*$ & $1.26 \mathrm{E}+07$ & $1.26 \mathrm{E}+08$ & $1.26 \mathrm{E}+07^{\dagger}$ & $1.26 \mathrm{E}+08^{\dagger}$ \\
\hline $\mathrm{C}-14$ & $1.52 \mathrm{E}+03$ & $*$ & $8.45 \mathrm{E}+03^{\ddagger}$ & $8.45 \mathrm{E}+04^{\ddagger}$ & $8.45 \mathrm{E}+04^{\dagger}$ & $8.45 \mathrm{E}+04^{\dagger}$ \\
\hline Co-60 & & $2.71 \mathrm{E}+04$ & $1.92 \mathrm{E}+03$ & $2.98 \mathrm{E}+01$ & $1.15 \mathrm{E}+06$ & $1.79 \mathrm{E}+04$ \\
\hline Sr-90 & & $3.11 \mathrm{E}+05$ & $6.49 \mathrm{E}+02$ & $2.28 \mathrm{E}+03$ & $8.43 \mathrm{E}+04$ & $2.97 \mathrm{E}+05$ \\
\hline $\mathrm{Zr}-95$ & & $4.34 \mathrm{E}+04$ & $3.64 \mathrm{E}+03$ & $2.98 \mathrm{E}+02$ & $2.18 \mathrm{E}+07$ & $1.79 \mathrm{E}+06$ \\
\hline Nb-95 & & $2.56 \mathrm{E}+05$ & $1.07 \mathrm{E}+02$ & $1.73 \mathrm{E}+03$ & $1.71 \mathrm{E}+05$ & $2.77 \mathrm{E}+06$ \\
\hline $\mathrm{I}-131$ & & $5.40 \mathrm{E}+05$ & $3.50 \mathrm{E}+02$ & $3.20 \mathrm{E}+02$ & $2.66 \mathrm{E}+04$ & $3.20 \mathrm{E}+03$ \\
\hline Cs-134 & & $1.28 \mathrm{E}+05$ & $3.84 \mathrm{E}+02$ & $2.47 \mathrm{E}+03$ & $1.04 \mathrm{E}+06$ & $6.66 \mathrm{E}+06$ \\
\hline Cs-137 & & $5.33 \mathrm{E}+04$ & $9.24 \mathrm{E}+01$ & $2.53 \mathrm{E}+03$ & $2.49 \mathrm{E}+05$ & $6.83 \mathrm{E}+06$ \\
\hline
\end{tabular}

* In most cases, the air concentrations of HTO and C-14 are available and can be used to ensure the protection of biota. In rare cases where soil concentrations are required, they can be calculated using the specific activity model.

${ }_{\ddagger}^{\ddagger}$ Unit is $\mathrm{Bq} / \mathrm{g}$ dissolved inorganic carbon in water for $\mathrm{C}-14$.

$\dagger$ Units are $\mathrm{Bq} / \mathrm{L}$ of sediment water for $\mathrm{HTO}$; and $\mathrm{Bq} / \mathrm{g}$ total organic carbon in sediment for $\mathrm{C}-14$.

\section{Acknowledgments}

We thank our partners in the CANDU Owners Group for funding this study.

\section{References}

[1] Chouhan S.L., Yankovich T.L. and Davis P.A., Generic environmental concentrations below which no effects are expected on non-human biota in Canada, CANDU Owners Group Report COG-053068, 2006.

[2] FASSET - Framework for Assessment of Environmental Impact, Final Report. A project within the EC $5^{\text {th }}$ Framework Programme, Contract No: FIGE-CT-2000-00102, Project Co-ordinator: Swedish Radiation Protection Authority, 2004. www.erica-project.org. 
[3] IMPACT User Manual Version 4.0. Stantec Consulting Ltd., 14 Abacus Road, Brampton, Ontario, Canada, 2003.

[4] RESRAD-BIOTA: A tool for implementing a graded approach to biota dose evaluations, U.S. DOE User's Guide, Version 1, DOE Report No. DOE/EH-0676, 2003. http://homer.ornl.gov/oepa/public/bdac/.

[5] UNSCEAR (United Nations Scientific Committee on the Effects of Atomic Radiation), Effects of Ionizing Radiation on the Environment. A/AC.82/R.549, United Nations, Vienna, 1996.

[6] Kotzer, T.G. and Kramer-Tremblay, S., Behaviour of radiocarbon in the freshwater environment around CANDU nuclear power generating stations, CANDU Owners Group Report COG-01-080, 2003. 